Article

\title{
American Better Business Bureaus, the Truth-in-Advertising Movement, and the Complexities of Legitimizing Business Self-Regulation over the Long Term
}

\author{
Edward J. Balleisen \\ History Department, Duke University, Durham, NC 27708-0719, USA; E-Mail: eballeis@duke.edu
}

Submitted: 30 September 2016 | Accepted: 10 November 2016 | Published: 15 March 2017

\begin{abstract}
This essay considers the question of how strategies of legitimatizing private regulatory governance evolve over the long term. It focuses on the century-long history of the American Better Business Bureau (BBB) network, a linked set of businessfunded non-governmental organizations devoted to promoting truthful marketing. The BBBs took on important roles in standard-setting, monitoring, public education, and enforcement, despite never enjoying explicit delegation of authority from Congress or state legislatures. This effort depended on building legitimacy with three separate groups with very different perspectives and interests - the business community, a fractured American state, and the American public, in their roles as consumers and investors. The BBBs initially managed to build a strong reputation with each constituency during its founding period, from 1912 to 1933 . The Bureaus then in many ways adapted successfully to the emergence of a more assertive regulatory state from the New Deal through the mid 1970s. Eventually, however, the resurgence of conservative politics in the United States exposed the challenges of satisfying such divergent stakeholders, and led the BBBs to focus resolutely on shoring up its support from the business establishment. That choice, over time, undercut the Bureaus standing with other stakeholders, and especially the wider public. This history illustrates: the salience of generational amnesia within private regulatory institutions; the profound impact that the shifting nature of public faith in government can have on the strategies and reputation of private regulatory bodies; and the extent to which private regulators face long-term trade-offs among strategies to sustain legitimacy with different audiences. It also suggests a rich set of research questions for longer-term histories of other private regulatory institutions, in the United States, other societies, and at the international level.
\end{abstract}

\section{Keywords}

anti-fraud regulation; Better Business Bureaus; ethnography of regulatory governance; history of self-regulation; institutional reputation; legitimization trade-offs

\section{Issue}

This article is part of the issue "Legitimization of Private and Public Regulation: Past and Present", edited by Klaus Dieter Wolf (Peace Research Institute Frankfurt, Germany), Peter Collin (Max Planck Institute for European Legal History, Germany) and Melanie Coni-Zimmer (Peace Research Institute Frankfurt, Germany).

(C) 2017 by the author; licensee Cogitatio (Lisbon, Portugal). This article is licensed under a Creative Commons Attribution 4.0 International License (CC BY).

\section{Introduction}

Modern self-regulatory bodies-that is, non-governmental institutions associated with the business community that set regulatory standards, engage in public education about those rules, monitor how firms live up to them, and even sanction those enterprises that violate their requirements-operate against a back- drop of skepticism. Such institutions, of course, have a very long history, substantially pre-dating the emergence of technocratic public regulatory agencies. For centuries, European guilds and professional societies set the terms of market activity in specific sectors (De Moor, 2008). As countries industrialized in the nineteenth- and early twentieth-centuries, leaders in many economic sectors invented new forms of self-regulation. In some 
cases, as with the creation of stock and commodity exchanges, the goal was to coordinate market activity; in others, the objective was to respond to problems associated with industrialization, like the difficulties of ensuring pure milk for urban consumers or the "smoke nuisance" that bedeviled so many fast-growing cities. (Adams, 1908; Uekotter, 1999). But as concepts of democratic sovereignty began to spread in the wake of the American and French Revolutions, self-regulatory organizations faced new and growing challenges to their legitimacy that have only intensified over the past century.

Business-owners and managers sometimes, and perhaps often, view private regulatory organizations as busybodies that are almost as intrusive as governmental regulators. Upstart firms in particular tend to equate selfregulatory efforts schemes with anti-competitive measures to shore up the market position of established firms. Legislators, state regulatory agencies, and the judiciary may all see self-regulatory bodies as threats to their own authority. Social activists and the broader public, meantime, frequently presume that private modes of regulation serve primarily to deflect pressures for more stringent governmental responses to economic or social problems. By contrast, defenders of self-regulation often argue that such institutional modes of governance can often address complicated regulatory problems more effectively than public regulation, and at lower cost. Such arguments often have particularly strong force when regulatory policy-making concerns highly technical questions in which corporations and industry insiders possess extensive expertise (Balleisen, 2010; Balleisen \& Eisner, 2009). Disputes over legitimacy, then, tend to swirl around private regulatory governance, raising interlinked questions about competence, effectiveness, and the appropriate sources of regulatory decision-making within democratic societies.

Scholars across the social sciences have come to understand these contested tropes about self-regulation. So too have policy-makers. From at least the early twentieth-century, state official in industrialized democracies have periodically fashioned strategies of coregulation, in the hopes of gaining the benefits of selfregulation while limiting its costs. With co-regulation, the state delegates significant regulatory functions to selfregulatory bodies, but retains supervisory authority over them. This complex approach to regulatory design has come to characterize such policy domains as: securities regulation, which across the world relies on accountants, corporate attorneys, and stock exchanges, as well as national regulatory bodies (Carson, 2011; McCraw, 1982); workplace safety regulation, in which governments often rely on work councils made up of union and company representatives to construct operational plans, which governmental officials audit (Gunningham \& Johnstone,
1999); and food safety regulation, in which national regulatory agencies increasingly rely on self-regulatory plans and implementation mechanisms created by corporations that process and distribute food products (Havinga, 2006; Sharma, Teret, \& Brownell, 2010).

For the most part, social science research into how private regulators try to legitimate their authority takes the form of intensive case studies of a given regulatory institution over a fairly short period of time. Often, those case studies also only investigate issues of legitimation indirectly or as part of a wider consideration of the origins and impacts of self-regulation in a given context. ${ }^{1}$ This essay takes a much longer view, exploring the evolution of American Better Business Bureaus (BBBs) over more than a century. Such macro-historical perspective allows us to see how strategies to secure the institutional legitimacy of private regulation evolved in the face of new circumstances.

Dating from 1912, the BBBs began as local associations in American cities, run by volunteers within the American advertising sector who wished to root out deceptive marketing practices by consumer retailers, investment brokers, and the advertising firms on which they relied. Within fifteen years, BBB leaders had developed a national umbrella organization, raised funds from national corporations and local businesses to hire professional staff, lobbied to shape anti-fraud policies on the state and national levels, and built out institutional capacity around standard-setting, public education, and norm enforcement. They had also forged deep connections with print media editors and publishers, business leaders in the new domain of radio, trade associations throughout the economy, large-scale retail corporations, and state and federal officials responsible for regulating the truthfulness of commercial speech. In all of these activities, the BBBs articulated a cohesive philosophy of business self-regulation, predicated on the ethical demands of a businessmen's social movement for truth-inadvertising. Over the subsequent five decades, the BBBs adapted to a steadily more assertive regulatory state, always looking to carve out a substantial role for selfregulatory organizations, while accepting a more vigorous role for state regulatory oversight. From the 1970 s onwards, however, the BBBs confronted new pressures from within the business community and the political world, as a resurgent conservativism threatened its funding base and encouraged a less cooperative stance toward state regulatory institutions. ${ }^{2}$

This organizational history offers several insights about the challenges that non-governmental regulatory institutions confront as they seek to establish and sustain niches within ecologies of regulatory governance. The BBBs had to worry about three different, if sometimes overlapping types of legitimation. First, they had

\footnotetext{
${ }^{1}$ For wide-ranging examples, see the extensive literature cited in Balleisen (2010).

2 I give the institutional evolution of the BBBs close attention in a recent book (Balleisen, 2017). This essay draws heavily on the research for that volume, as well as a related 2009 article (Balleisen, 2009). Here I offer a more synoptic assessment of the BBBs' history in light of the core questions driving this comparative special issue.
} 
to build and then maintain a base of support among the business community. The most important imperative here was to attract funding from a sufficient cohort of entrenched firms, but the Bureaus also needed to cultivate a reputation for trustworthiness among a wider set of enterprises. Second, the BBBs sought to gain the trust of legislators and regulatory officials, not only as an important stakeholder deserving of respect in policy discussions, but also as a partner in rule-making, dissemination of norms, and enforcement of those standards. Finally, the Bureaus wished to earn and keep the trust of consumers and investors as vital arbiters of fair dealing in the American marketplace. The strategies of legitimation fashioned by the BBBs varied depending on the audience. In addition, BBB approaches to the challenges of legitimation also shifted, sometimes quite dramatically, with transformations in the wider socioeconomic, political, and policy environment.

The history of the BBBs, then, has involved multifaceted, changing modes of legitimation. No doubt the tangled threads in this narrative reflect the distinctive characteristics of the BBB network. The work of these private regulatory bodies ranged across much of the economy (rather than involving just one industry or sector, as is the case for many self-regulatory entities), and did not occur on the basis of explicit delegation of authority from the state (unlike, for example, the National Association of Securities Dealers, now known as the Financial Industry Regulatory Authority). The BBB network also occurred mostly within the confines of a single nation (though some Bureaus operated in some Canadian cities as well as in the United States). Nonetheless, I suspect that this case study also has more general implications for understanding the dilemmas faced by modern selfregulatory bodies that seek to forge positive reputations, whether for competence, fairness, democratic character, or effectiveness. No matter how durable the legitimacy of a given regulatory institution may seem at a given moment with a given constituency, wider socio-economic, cultural, and political shifts can recast the pressures bearing down on that institution, and hence its strategies of legitimation. In addition, there often will be trade-offs among legitimation strategies targeted at separate constituencies with different interests and points of view. That is, a successful campaign of legitimation with one stakeholder may, over time, risk de-legitimation with other stakeholders. ${ }^{3}$ By the same token, a private regulator that can lay claim to some effectiveness may, over time, lose sight of some of the sources of that regulatory success.

This essay first offers a brief sketch of the history of the BBB network, divided into three main periods-a founding era, from 1912 to 1933; a period of accommodation with a more assertive public sector, from 1933 through the early 1970s; and a period of reenergized conservatism, from the mid 1970s to the present. After this historical overview, the article considers the evolving strategies of legitimation adopted by this important institution of American business self-regulation. Leaders within all regulatory institutions, indeed leaders within all policy institutions, have to pay at least some attention to reputational considerations. But this imperative takes on distinctive dimensions for private regulatory institutions that lack the color of state authority.

\section{Origins}

The American Truth-in-Advertising movement represented, in part, a collective search for respectability and social standing. From the 1850 s into the early twentieth century, advertising agencies, newspapers, and magazines had depended on patent medicine advertisements for a significant share of income, and those ads notoriously made outlandish claims of miraculous impacts (Young, 1961). Even when advertising agencies attracted business from a wider set of products, their advertisements often embraced manipulative or deceptive tactics. As a result, advertising executives confronted negative stereotypes that depicted them as shady operators who lacked scruples. At the same time, some upscale marketers concluded that the prevalence of misleading claims in advertising copy had generated widespread public skepticism about advertising in general, reducing its capacity to move consumers to buy. ${ }^{4}$ For a cluster of advertising managers in more established agencies and corporate managers responsible for marketing, these concerns justified collective action to rein in the worst kinds of duplicity in the American marketplace.

The first efforts took place within Midwestern cities, beginning in Minneapolis, and then spread to urban centers around the country. In addition to organizing local "vigilance committees" devoted to an ideology of truthfulness in commercial speech, early leaders lobbied for new state laws that made false advertising a criminal misdemeanor. The biggest focus of these new urban organizations was on retail marketing practices. But in New York City, Boston, and other large eastern cities, the BBB (as they came to be called by the early 1920s) also targeted sales of unlisted securities (that is, investment vehicles not listed on one of the country's established stock exchanges). ${ }^{5}$

From the outset, the most important strategy of the BBBs was to educate consumers and investors so that they could sidestep bad deals and outright scams. The Bureaus churned out educational pamphlets, deputized spokespersons to speak to community organizations and write articles for city newspapers, and placed cautionary ads all over urban America. Alongside this strategy of pre-

\footnotetext{
${ }^{3}$ For a magisterial example of how the organizational reputation of a regulatory body can shift over time, see Carpenter (2010).

${ }^{4}$ Scholars such as Fox (1984); Marchand (1986); Lears, (1994); and Stole (2006) have probed the cultural debates prompted by these developments, which included intensifying attacks against advertising for claims that were exaggerated, misleading, or false.

${ }^{5}$ For a wide-ranging history/memoir of the early Truth-in-Advertising movement, see Kenner (1936).
} 
vention, BBBs established mechanisms to monitor marketing practices. Every BBB encouraged local residents to bring it complaints of unfair or unscrupulous sales tactics, and also surveyed local ads, and then sent out employees to see whether businesses lived up to their advertised promises. If a Bureau found evidence of deceptive selling, it would contact the business in question to seek redress. Should a firm refused to engage with BBB officials, they would publicize the incident in its publications (what scholars of business regulation would now call a strategy of "shaming") and even suggest that media outlets refuse its advertising business (a form of "shunning") (Gunningham \& Rees, 1997; King \& Lennox, 2000; Porter \& Ronit, 2006).

Such ambitious self-regulatory efforts soon outstripped the capacity of volunteers, leading the BBBs to create full-time professional staffs within a few years of their creation, funded by membership dues from local businesses. ${ }^{6}$ By the end of the 1920s, the BBB network had more employees than the United States Federal Trade Commission (FTC), which was responsible not only for regulating deceptive marketing in interstate commerce, but also the oversight of antitrust law. The Bureaus had also established a continental association, the National Better Business Bureau, to share intelligence and organizational strategies among local organizations.

\section{The BBBs amid a Consolidating Regulatory State}

During the 1910s and 1920s, the BBBs cultivated close relationships with the American state at every jurisdictional level. In addition to lobbying for tighter legal prohibitions against deceptive marketing, including state-level criminal prohibitions against false advertising, the Bureaus worked closely with trade associations and the FTC to draft sectoral "trade practice rules". These compilations laid out detailed standards for business communication in scores of specific industries. The BBBs further built strong links to local, state, and federal prosecutors. If established businesses engaged in duplicitous marketing and ignored BBB efforts to convince them to change their ways, or if firms embraced outright swindles, BBB officials did not hesitate to refer cases to the criminal justice system. Such referrals occurred roughly once for every one hundred BBB investigations. In this initial phase, the BBBs more often than not defined the course of antifraud policies (Balleisen, 2009).

The emergence of New Deal policies and institutions as responses to the Great Depression, and then the extension of consumer-protection measures in the postWorld War II decades, moved American anti-fraud policies away from the nineteenth-century preference for a logic of caveat emptor (let the buyer beware), and toward a logic of caveat venditor (let the seller beware.) In the process, these policies curbed the Bureaus' capacity to influence the broad direction of anti-deception regulation. Confronting far more vigorous regulatory muscleflexing by American governments from the 1930s to the 1970s, Bureau leaders mostly adopted a stance of accommodation. That is, they accepted the general trend, while attempting to shape its specific implications.

In the policing of fraudulent investments and deceptive marketing or trading of securities, the BBBs gave way before a new regulatory complex that was centered on the new national Securities \& Exchange Commission, but also incorporated a panoply of other self-regulatory bodies (stock exchanges, professional organizations of auditors and accountants, and the new National Association of Securities Dealers). In other domains, like deceptive retail marketing, the BBBs looked to deepen their engagement with public authorities. Scores of BBB officials participated in the sectoral code authorities established by the Roosevelt Administration's short-lived National Recovery Administration, helping to define and enforce public instantiations of trade practice rules (Chicago Tribune, 1933; New York City Better Business Bureau, 1933). For a quarter century after the Supreme Court struck down the NRA as unconstitutional, BBB leaders continued to collaborate with trade associations and the FTC. Together, business associations, the BBBs, and FTC officials convened sectoral trade practice conferences and drafted voluntary sectoral fair practice standards, which despite their voluntary nature guided FTC enforcement of its general prohibitions against deceptive business practices in interstate trade (FTC, 1958, 1959; The Yale Law Journal, 1953).

From the late 1950s through the middle 1970s, state and local governments increasingly challenged BBBs as champions of consumer protection in local markets. Across the country, city councils, metropolitan counties, and state legislatures passed a raft of ordinances and law that tightened restrictions on deceptive or fraudulent marketing. State and local authorities further created new consumer protection agencies that had responsibilities like those of the BBBs. That is, the new consumer protection bureaus invested heavily in public education, monitored marketplaces, served as complaint clearinghouses, and engaged in informal mediation between disgruntled consumers and retail firms. ${ }^{7}$

Even though these state bodies directly competed with BBBs for the attention and loyalty of urban consumers, most BBB officials settled on a strategy of cooperation, viewing any other stance as asking for public condemnation in an era of growing consumer activism. These leaders had begun their BBB careers during the Great Depression or in World War II. While they retained a fervent belief in the importance of business selfregulation, they had grown accustomed to more expansive state efforts at investor and consumer protection, and saw little value in challenging the direction of public

\footnotetext{
${ }^{6}$ An early annual report from the Boston Better Business Commission (as the local BBB branch initially called itself) offers a particularly extensive overview of early BBB philosophy and strategy (The Boston Better Business Commission, 1922).

${ }^{7}$ For a concise overview of these developments, see Bruns (1974).
} 
policy. ${ }^{8}$ Indeed, toward the end of this period, the BBBs sometimes emulated public consumer-protection institutions, nowhere more so than in the decision of many Bureaus during the late 1960 s and early 1970 s to create branch offices in inner city neighborhoods, bringing BBB education initiatives and consumer services to previously ignored communities.

\section{A Conservative Pivot}

Beginning in the mid-1960s, however, a growing number of younger BBB officials, especially from Sun Belt cities like Atlanta, Houston, and Phoenix, chafed under the longstanding BBB stance of accommodation. These individuals were influenced by experiences in corporate America and their region's renewed conservatism, rather than decades-long acculturation with the realities of expanded regulatory power. Aligning themselves with the growing critics of regulatory overreach, they voiced opposition to frequent, cozy interactions between BBB officials and public regulators. As one Atlanta BBB leader put it in 1965:

We in Atlanta have long ago decided that our local problems can be best be handled on a local basis and without the assistance of the FTC, SEC,...Food and Drug Administration, or whatever....We do not receive one dime from the government and don't want any of their money. By the same token, we don't want any of their publicity. We are supposed to speak for business....Our conversations should be business conversations, and our files should be business files, and our information should be business information, and our reports should be business reports, and our standards should be business standards.... If we are to play cops and robbers, then I think we should change the misnomer we call a slogan, "Private Enterprise In the Public's Interest", to "Business Supported Agencies for the Purpose of Squealing on Business".

In addition to calling for reinvigorated connections to corporate America, the conservatives also argued that the BBBs needed to develop a more sustainable business plan. The latter stance included support for allowing individual businesses that joined a local BBB to advertise that fact, something that the Bureaus had refused to do for more than a half-century..$^{9}$

As economic stagnation in the 1970s gave a boost to conservative politics and policies, such views gained more purchase within the BBBs. Over the course of the 1980s and 1990s, the BBBs invested far less in public education, though they did build out an early presence on the internet. In the early 1980s, the national umbrella organization declared that local BBBs could allow businesses to communicate their membership through a BBB symbol on storefronts and via advertisements. Local BBBs also became far less likely to refer businesses to regulatory agencies or criminal prosecutors. During the 1990s and 2000s and at the behest of retailers who wanted a means of deflecting consumer complaints, most BBBs began to offer formal arbitration as a means of settling consumer disputes. The Bureaus further instituted a grading system for businesses (from $A$ to $F$, as with marks in American education), a move that has occasioned allegations that the BBBs offer excellent grades to members regardless of their business practices, and give poor marks to many non-member businesses, again regardless of their record of complaints and adjustments (Ambrose, 2009; Belkin, 1984; Los Angeles Sentinel, 1979; Oldenburg, 1997). On the whole, the BBB network moved closer in its mission and organizational culture to the interests of those businesses who provided it with funding.

\section{Patterns of Legitimization and De-Legitimization}

This historical overview provides essential context for any attempt to reflect on shifting practices of legitimation during the more than one hundred years that the BBBs have been a part of anti-deception regulation in the United States. Since its inception, the BBB movement has been obsessed with questions of legitimacy. But one must take care to distinguish three separate constituencies through which BBB leaders have sought to establish and sustain reputation and authority: the business community; the state; and the wider investing and consuming public. The balance of concern for these stakeholders has shifted greatly across the past century, as have the strategies and tactics that BBB officials have pursued in either creating or sustaining their legitimacy with one or another of the three groups.

In the BBB's founding era, organizational leaders wished to improve the standing of marketers in general, and advertising agencies in particular. This goal required that they convince a critical mass of the business community to accept the principles of "truth in advertising", not just in the abstract, but through financial contributions that would support a robust bureaucratic infrastructure and through acceptance of BBB authority to determine what counted as deceptive marketing. In part, early BBB officials gained traction within the business community through sustained efforts at moral suasion. Drawing on the culture and values of evangelical Protestant Christianity, BBB leaders exhorted corporate executives and small business-owners to live up to a higher creed than the relentless pursuit of short-term profit. Rituals and good fellowship at local meetings and national conferences proved to be crucial elements of these efforts at

\footnotetext{
${ }^{8}$ W. Dan Bell, the head of the Denver Better Business Bureau for more than two decades after World War II, exemplified BBB professionalism. See his extensive papers at the Denver Public Library.

9 James Stephens to Dan Berry, Jr., August 26, 1965; Dan Berry, Jr., “There Are Termites in the Basement," August 30, 1965, both in W. Dan Bell Papers, Denver Public Library.
} 
community organizing. So too did arguments that even the best-intentioned firms could benefit from checks and balances on their day to day practices. Some department store executives welcomed the development of BBB ad monitoring, on the grounds that it would curb any deceptive or manipulative selling practices that might be fostered by commission-based compensation frameworks (Accuracy, 1925; Balleisen, 2009).

The BBBs further appealed to the aversion that many businessmen had to expansive exercise of state power, a key theme in scholarly accounts of the circumstances that foster the creation of self-regulatory institutions (Balleisen \& Eisner, 2009). BBB standard-setting, monitoring, and informal modes of enforcement-all conceptualized as business "home rule" - offered the prospect of staving off the expansion of more intrusive statebased investor and consumer protection regulations. This line of argument was also attractive to Republican elected officials such as Presidents Calvin Coolidge and Herbert Hoover, who shared a strong skepticism of expansive state bureaucracy, preferring public coordination of self-regulatory organizations (Accuracy, 1926; Hawley, 1981; New York Times, 1930).

A further source of legitimacy for the early BBB network involved perceived regulatory effectiveness, which mattered not only to businesses, but also to public officials, investors, and consumers. Through the 1920s, the BBBs took every opportunity to burnish their credentials as inveterate opponents of marketplace deceptions and as institutions with technocratic expertise in rooting them out. In addition to developing vigorous campaigns of public education, BBB leaders pushed their activities into the public spotlight at every opportunity, relying heavily on close relationships with urban newspapers and national magazines. In hundreds of articles published across the country, the consistent message was that the BBBs had quickly learned how to: convene standard-setting deliberations about fair business practices within specific sectors; build out monitoring mechanisms for urban marketplaces (which depended on corps of female shoppers who would check on whether firms lived up to their promises in advertisements); and deftly mediate complaints that consumers and investors had against retail firms. All of this expertise, moreover, ostensibly rested on the capacity of BBBs to act quickly, informally, and at much lower cost than governmental agencies. ${ }^{10}$

A 1937 cartoon that appeared in the Cleveland Plain Dealer (Figure 1) nicely conveys the BBB's the message of effectiveness. The artist depicts the organization as a beneficent sun, which disinfects the urban marketplace through its powerful rays of actionable information about business practices. Recognizing how difficult the city's environment has become for deceptive salesmanship, a "Business Faker", sweating profusely from the power of anti-fraud light and heat, turns tail and heads elsewhere in search of easier marks.

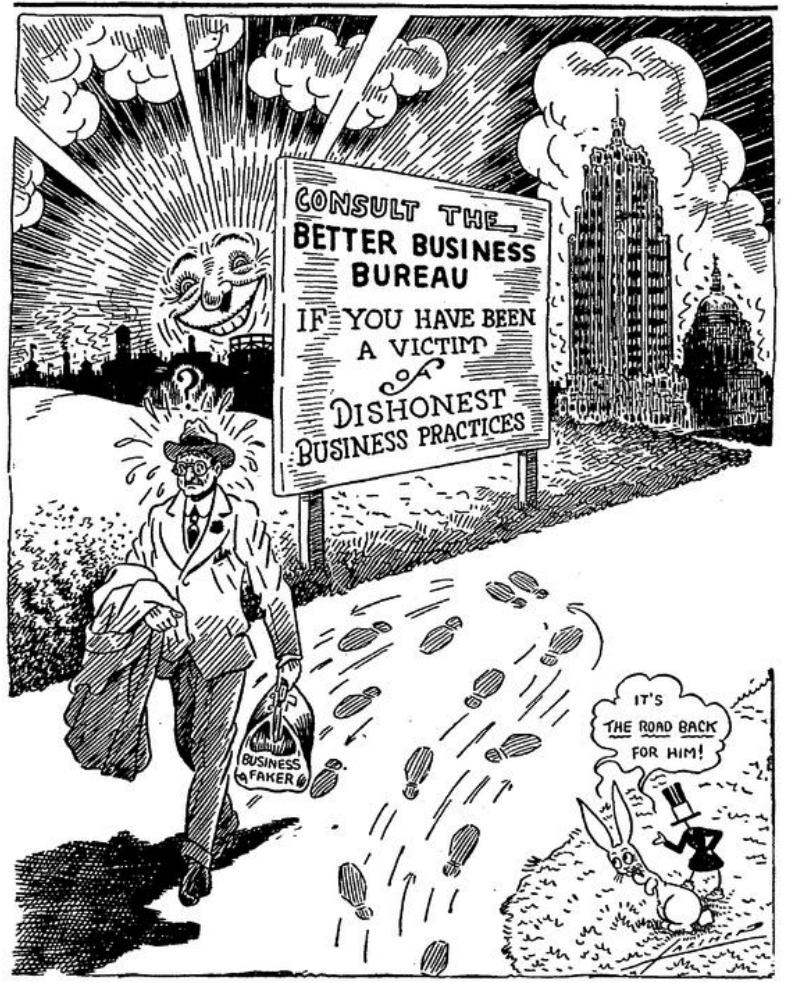

Figure 1. Depicting the ostensible impact of BBB antifraud work. Source: Cleveland Plain Dealer (1937).

There were scattered dissenters to such rosy depictions of BBB regulatory undertakings. Retailers and stock promoters whose business practices received condemnations from the BBBs lambasted them as unelected busybodies whose surveillance methods and coercive threats of public shaming lacked a shred of legitimacy, especially in a society that valued fairness and due process. For these critics, the BBBs constituted a protection racket, extracting membership dues from businesses as the price of not facing BBB ire, and insulating entrenched firms from competition. Indeed, some businesses on the receiving of negative publicity from a Bureau went so far as to sue the organization for libel (Justia, 2016; Riegel, 1931; O'Sullivan, 1933; The Lance, 1933).

Despite such criticisms and occasional legal attacks, urban populations and governing elites both quickly came to see the BBBs as valuable institutions. By the late 1920s, BBBs annually attracted tens of thousands of inquiries and complaints from consumers and investors who wanted information about a business or assistance with a grievance. The network enjoyed financial support from the largest department stores, smaller retailers, and the nation's investment banks. They had forged close links to urban district attorneys, some state attorneys general, and federal officials at the FTC. The BBB network had, in other words, gained significant institutional legitimacy. Outcomes in defamation suits against local Bureaus reflected this level of esteem, as state and federal courts routinely ruled in their favor (The Boston BBB Bulletin, 1929).

\footnotetext{
10 Kenner's The Fight for Truth in Advertising discusses each of these features of BBB strategy and tactics at great length.
} 
During the New Deal, World War II, and post-World War II decades, the BBBs confronted a series of new political, legal, and economic realities that encouraged reorientation of its strategies of legitimation. The organization continued to stress the efficiencies of its selfregulatory practices, as well as the extent to which most businesses accorded them respect. But it added new twists, such as a more sustained linkage of its activities and ethos to American anti-communism. BBB leaders additionally emphasized, more so than in their first two decades, that they possessed a degree of independence from the corporations, partnerships, and proprietorships that floated their operations. They described themselves as the "umpires of American business advertising", likening themselves to dispassionate sports referees who ensured a level playing field for vigorous capitalist competition. ${ }^{11}$

The mid-century BBBs, moreover, had to cope with a much more assertive regulatory state. Where possible, BBB leaders looked for ways to meld their own operations with those of regulatory agencies, as with the shortlived code authorities of the Depression-era National Recovery Administration, or the FTC's prioritization of regulatory campaigns against bait and switch advertising and fictitious pricing tactics in the late 1950s. Where necessary, they ceded ground, as with securities regulation, which the BBBs left to the SEC and financial industry self-regulatory bodies. At all points, they worked to sustain operational integration with regulatory institutions at every jurisdictional level of government. That goal depended on the cultivation of ongoing relationships with regulatory officials, whether through discussions about rule-making and priorities for enforcement activities, or through information sharing. ${ }^{12}$

On the whole, the BBBs retained considerable standing throughout these decades. Amid remarkable postwar prosperity, businesses continued to fund BBB operations. Indeed, the BBBs expanded coverage not only to more than a score of new cities in the 1950s and 1960s, but also to suburban neighborhoods through the opening of new branch offices. The urban public continued to rely on BBB services, with annual inquiries and complaints reaching into the millions. National political leaders, including every President from Roosevelt through Nixon, publicly commended the BBBs as a vital element in the nation's anti-fraud/deception infrastructure. ${ }^{13}$

Moreover, the BBBs in this era were at least occasionally willing to scrutinize the marketing practices of larger corporations as well as smaller firms. From 1966 through 1968, for example, BBBs around the country co- ordinated a multi-year investigation of bait and switch tactics at many Sears department stores, one of the country's most powerful corporations. After consumers were lured into Sears stores by ads detailing low prices for durable consumer goods like vacuum cleaners, salespersons would try to convince them to purchase a more expensive product. BBB officials around the country consistently brought such behavior to the attention of Sears' executives in their communities, who repeatedly apologized, offered to adjust the concerns of any disgruntled customers, and pledged to clamp down on such selling practices. ${ }^{14}$

Nonetheless, challenges to BBB legitimacy intensified from the 1950 s onwards. Although many national corporations and entrenched local businesses remained committed to BBB work during this era, a growing number of firms issued complaints about the lack of due process in BBB enforcement efforts. This concern had emerged as early as the 1920s, when the New York City department store Macy's faced a BBB demand that it drop its claim that it offered the lowest prices in the city, since its goods periodically were undercut by competitors. After a long negotiation, Macy's resigned from BBB membership rather than cede a degree of control over its marketing (The New York Better Business Bureau, 1926). During the post-World War II decades, worries about procedural fairness were sharpened by legal reforms in public regulation. Most notably, the 1946 Administrative Procedure Act (APA), enacted at the behest of business interests, imposed far more stringent standards of procedural fairness in administrative enforcement actions undertaken by federal regulatory agencies (Grisinger, 2012).

Several BBBs responded to the new focus on due process by emulating aspects of the APA. These Bureaus established local review boards that would entertain appeals from businesses who objected to BBB determinations that their advertising or other business practices were deceptive. These boards would hold hearings in which firms would enjoy many procedural rights, such as the right to be represented by an attorney, and the right to see evidence compiled against them. In the early 1970s, the national BBB followed suit, creating a review board related to its monitoring of nationwide broadcast and magazine advertising. But these efforts at solidifying legitimacy with some businesses came with costs. To the extent that procedural protections delayed quick regulatory action (such as publicizing BBB determinations of deceptive practices), it limited regulatory effectiveness. In addition, the Federal Trade Commission ruled that the BBBs had to be careful in structuring any ap-

\footnotetext{
11 Kenneth Barnard to Clyde Kemery, March 23, 1960, Box 6, Folder 1, Better Business Bureau of Metropolitan Chicago Records, Chicago History Museum.

12 The records of the Chicago Better Business Bureau, held by the Chicago History Museum, furnish especially detailed evidence about the degree of cooperation between BBB representatives and regulatory officials in the states and federal government. See for example the letters, pamphlets, and internal memos in Box 15, Folder 2, concerning relations between the Chicago BBB and the new Illinois Consumer Fraud Bureau in the early 1960 s.

${ }^{13}$ For an overview of post-World War II growth in BBBs, as well as the endorsements provided by Presidents Truman, Eisenhower, and Kennedy, see Facts You Should Know about Your Better Business Bureau: Public Service of Private Business in the Public Interest (circa early 1960s), Box 9, Folder 2, BBB of Metropolitan Chicago Records, Chicago History Museum; Changing Times (1965).

14 See the set of letters and memos on the Sears investigation in Box 209, Folder 4, Better Business Bureau of Metropolitan of Chicago; and correspondence among BBB officials across the country about the Sears issue in Box 1, W. Dan Bell Papers, Denver Public Library.
} 
peals processes and enforcement actions, since compulsory sanctions would violate the FTC's regulatory jurisdiction (Albuquerque Journal, 1966; FTC, 1966; Van Cise, 1966; Zanot, 1979).

The BBB network also came under increasing fire during the late 1960s and early 1970s for not sufficiently expanding capacity to be able to keep track of the consumer marketplace, or to handle a crush of complaints encouraged by the growth of organized consumerism. Staff at individual bureaus struggled to keep files about local businesses up-to-date; they even struggled to answer the unending stream of phone calls that bombarded BBB offices. The urban riots of the 1960s further placed a media spotlight on pervasive consumer frauds and rip-offs in poor urban neighborhoods, which the BBBs had largely ignored. All of these critiques received a thorough airing through an investigative report commissioned by a New York City congressman, Benjamin Rosenthal, in the early 1970s (Congressional Record, 1971).

Institutional responses to erosion in popular legitimacy took two opposing tacks. Some local BBBs, such as the one in New York City, calculated that they had to make further concessions to the consumer movement, and looked to hire new leaders from its ranks, as well as to invest more heavily in consumer outreach (Cerra, 1978). But especially in the Sun Belt, BBBs tilted toward the preferences of the more conservative, businessfocused leaders who had begun to assume positions of authority. Their concern rested more on the need to retain legitimacy in the eyes of the corporations and local enterprises who supplied the fees that allows the BBBs to function. Even in a city like Chicago, leadership transitions could dampen ardor for taking on the big boys. Despite the extensive evidence that the Chicago BBB compiled about the deceptive selling techniques of Sears' employees, the Bureau shied away from publicly challenging Sears; sterner action against bait and switch selling at the retailer only occurred some years later, in 1976, when the Federal Trade Commission publicly cited the firm for deceptive selling practices (Wall Street Journal, 1976). ${ }^{15}$

As noted above, the inclination to reestablish tighter relations with the business establishment became more and more powerful in the subsequent four decades. This impulse drove the decisions to allow firms to display their BBB membership, to shy away from close cooperation with government consumer protection officials, and then to issue public grades of businesses as a means to bolster their supposed good reputation. Confronting a resurgent conservativism in large swaths of the business community, and a wider political turn toward deregulation and the older ethos of caveat emptor, the BBBs worried less about their standing with government officials and consumers, and more about their standing with private sector funders. The imperatives of epistemic legitimacy (showing government agencies and citizens that BBBs had expertise in keeping abreast of prevalent frauds and assisting public regulators in constraining them) accordingly diminished. So too did concern about the demonstration of professional autonomy. By contrast, attention to procedural legitimacy within local business communities expanded, as signified by the heavy investment that BBBs put into arbitration services.

Public reputation ebbed as a result of these intersecting shifts. As late as the 1960s, the BBB network could lay claim to considerable legitimacy from each of its three main constituencies (business leaders, government regulators, and the wider public, particularly in urban America, where they established their operations). Most Americans who lived in metropolitan areas knew about the BBB network; indeed a Roper public opinion survey in 1967 found that $81 \%$ of Americans were familiar with it, despite its thin reach into small towns and rural areas (National Better Business Bureau Bulletin, 1967). Governmental regulators also mostly continued to view the BBBs as key partners in regulating the truthfulness of commercial speech. Even as late as 1975, one could encounter an editorial cartoon in a major newspaper like the Chicago Tribune that implicitly characterized the BBBs as effective policemen of the advertising world. In this case (figure 2), a surgeon coming out of an operating theatre sees a headline suggesting that the longstanding prohibition on advertising by doctors might be coming to an end. His response, that he has no intention to "mess with the Better Business Bureau", communicated that the BBBs still enjoyed a reputation as powerful monitors whom businesses were bound to respect.

By the 2000s, however, far fewer Americans had a clear sense of the BBBs purpose or impact, and there was much less confidence that it would assist in mediating consumer complaints. Indeed, the BBBs began to confront regular, stinging criticism from a slew of consumer websites, as well as negative press coverage. The most recent critiques allege that the organization operates less as a regulatory institution and more as a means of bucking up the reputation of businesses that engage in the sort of commercial behavior that prompted creation of the BBBs more than a century ago. ${ }^{16}$ In these accounts, the BBBs had chosen to emulate the common tropes of self-regulatory organization as smoke screen or window dressing, as a means of appearing to rein in business, without actually doing so (Coombs \& Holladay, 2011).

The evolution of American BBBs suggests the analytical pay-off of tracing modes of private regulatory governance over the long term. Whether those modes involve industry associations, third-party Non-Governmental Organizations and private auditors, or self-regulatory units within businesses themselves, the challenges of legitimatizing regulatory authority almost always involve multiple constituencies. Private regulatory institutions may view those constituencies as equally important or of varying importance; they may adopt strategies of legitimation that cut across these groups, or tailor strate-

\footnotetext{
15 Report on Sears, Roebuck, October 1974, Box 209, Folder 5, Records of the Better Business Bureau of Metropolitan Chicago.

16 See for example, Roos (2008); Tuttle (2013).
} 


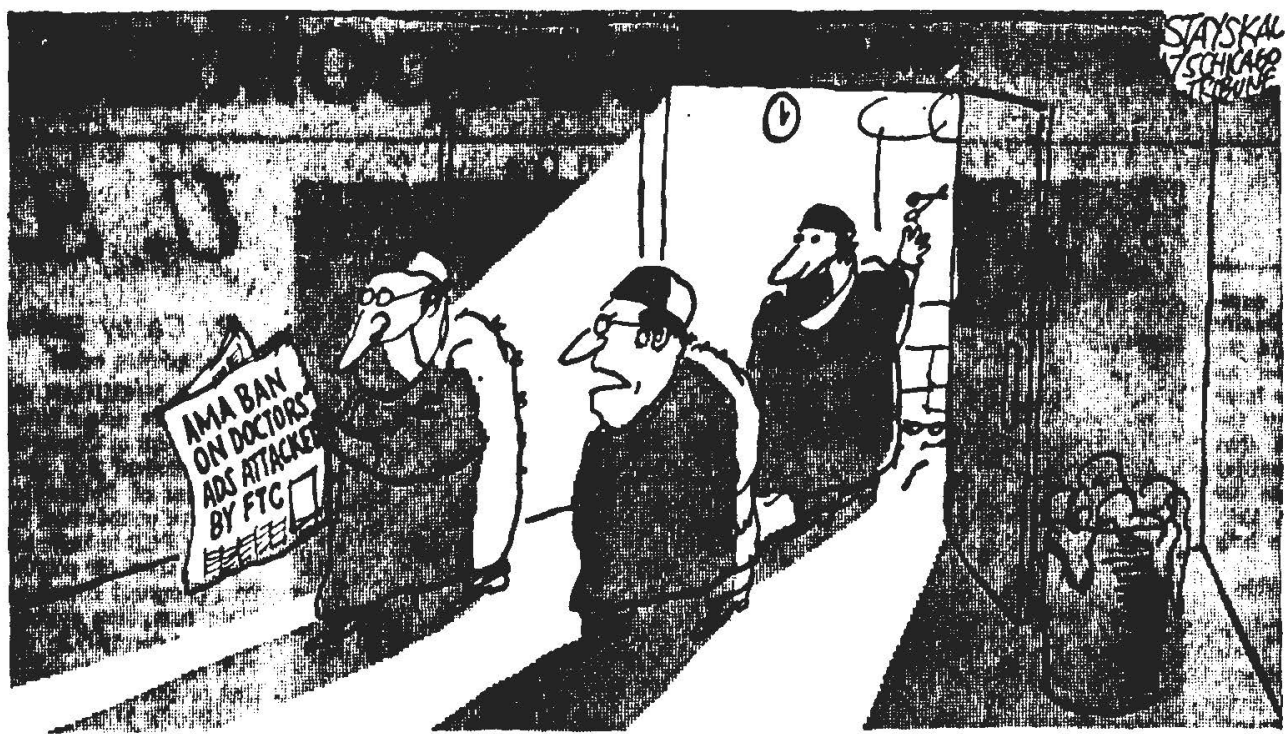

"I'll never advertise. . . . Got onough trouble with malpractice suits. . . . Don't need to mess with the Better Business Bureau, too."

Figure 2. The BBB as still powerful advertising gatekeeper. Source: Chicago Tribune (1975).

gies to specific ones. And their calculations invariably change with shifting political fortunes, economic pressures, and socio-cultural realities. One potential dynamic worth keeping in mind is institutional amnesia, especially over generational time frames. The early BBBs fostered extensive professionalization among its leaders, as well as an esprit de corps that insulated it at least partly from the views and preferences of its corporate and smaller business sponsors. As those early cohorts of officialdom retired, however, the organizations proved more amenable to a redirection of purpose, along with an associated redirection of legitimation strategies.

The long-term history of the American Truth-in-Advertising movement also suggests that the individuals responsible for directing non-governmental modes of regulation remain attuned to wider currents of trust (or skepticism) in the organs of state power. As popular faith in American government waxed during the middle third of the twentieth century, the BBBs adopted strategies and public justifications predicated more on co-regulation than self-regulation, with greater acceptance of policy direction from the state. As popular faith in American government waned during the final quarter of the twentiethcentury, the BBB network's practice, ethos, and presentation rejected co-regulation as the most appropriate frame for regulating candor in the marketplace.

A third implication of this organizational history concerns the potential for, and perhaps the likelihood of, trade-offs in the pursuit of institutional reputation. For roughly a half-century after their founding, the BBBs managed to build legitimacy with each of their major stakeholders - the business community, the state, and the wider public. But as differences in the perspective and interests of these constituencies widened in the 1970s, BBB leaders found that steps to sustain or deepen standing with one of these groups risked undermining legitimacy with others. Thus the turn to curry favor with businesses in the 1980s and 1990s eventually undercut popular faith in BBB's independence and commitment to consumer interests.

One can only discern such patterns and turning points by taking the long view - that is, by reconstructing the historical evolution of private regulatory bodies. An obvious next step would be to compare the dynamics of legitimation at the BBBs with other longstanding selfregulatory entities, to assess how much the BBB story reflects a common trajectory for modern self-regulatory institutions. In the American case, some obvious points of comparison would be stock and commodity exchanges, accrediting bodies for the professions, Underwriters' Laboratory, which sets safety standards for consumer products, and sectoral organizations such as the Institute of Nuclear Power Operators and the Motion Picture Association. ${ }^{17}$ There are, of course, numerous analogues in other societies, as well as international self-regulatory bodies. Many of the former, like European Chambers of Commerce, have much longer histories than the BBBs (Bennett, 2011). Some of the latter, like the International Standards Organization, have existed for roughly the same amount of time. (Murphy \& Yates, 2009). Others are more recent creations. The intensification of globalization over the last four decades has encouraged the creation of myriad international third-party mechanisms of regulatory governance, especially within the domains of environmental and labor standards, though many of these bodies have staked out ground that emphasizes

\footnotetext{
17 For an overview of many of these institutions, along with citations to a wide social science literature on them, see Balleisen (2014).

18 For entry points into a voluminous scholarship, see: Bartley (2007); Vogel (2010).
} 
a lack of dependence on businesses and trade associations. ${ }^{18}$ A collection of historical case studies, both within and across national boundaries, will be crucial to identify more general patterns in attempts to legitimate private regulation, as well as the impacts and ironies of those efforts.

\section{Acknowledgements}

The author would like to thank research assistants Caroline Wang and Anna Johns for their help with preparing this essay. I have received excellent feedback on earlier drafts from two anonymous peer reviewers and the participants in the workshop on "The Legitimization of Private and Public-Private Regulation: Past and Present" at the Max Planck Institute for European Legal History. The research underpinning my analysis has been supported by the American Council of Learned Societies, the National Humanities Center, the Tobin Project, Harvard Business School, and Duke University.

\section{Conflict of Interests}

The author declares no conflict of interests.

\section{References}

Accuracy. (1925, September). Department store has accuracy meeting. Accuracy, p. 1.

Accuracy. (1926, November). President Coolidge on truth-in advertising. Accuracy, p. 7.

Adams, S. A. (1908). The solving of the milk problem: How Copenhagen has established the feasibility of a pure and healthful supply. McClure's, 32, 200-207.

Albuquerque Journal. (1966, January 6). Ad club group studies forming review board. Albuquerque Journal.

Ambrose, E. (2009, March 10). BBB starts using letter grades. Baltimore Sun.

Balleisen, E. (2009). Private cops on the fraud beat: The limits of American business self-regulation, 18951932. Business History Review, 83(1), 113-160.

Balleisen, E. (2010). The prospects for effective coregulation in the United States: A historian's view from the early twenty-first century. In E. Balleisen \& D. Moss (Eds.), Government and markets: Toward a new theory of regulation (pp. 443-481). New York, NY: Cambridge University Press.

Balleisen, E. (2014). Rights of way, red flags, and safety valves: Regulated business self-regulation in the America, 1850-1940. In P. Collin, G. Bender, S. Ruppert, M. Seckelmann, \& M. Stolleis (Eds.), Regulierte selbstregulierung in der weslichen welt des späten 19. und frühen 20. Jahrhunderts/Regulated self-regulation in the western world in the late $19^{\text {th }}$ and early $20^{\text {th }}$ century (pp. 75-127). Frankfurt: Vittorio Klostermann.

Balleisen, E. (2017). Fraud: An American history from Barnum to Madoff. Princeton, NJ: Princeton University Press.
Balleisen, E., \& Eisner, M. (2009). The promise and pitfalls of co-regulation: How governments can draw on private governance for public purpose. In D. Moss \& J. Cisternino (Eds.), New perspectives on regulation (pp. 127-150). Cambridge: The Tobin Project.

Bartley, T. (2007). Institutional emergence in an era of globalization: The rise of transnational private regulation of labor and environmental conditions. American Journal of Sociology, 113(2), 297-351.

Belkin, L. (1984, May 31). Arbitration plan gains. New York Times.

Bennett, R. J. (2011). Local business voice: The history of chambers of commerce in Britain, Ireland, and revolutionary America, 1760-2011. Oxford: Oxford University Press.

Boston Better Business Commission. (1922). The Boston Better Business Commission. Boston: Boston Better Business Commission.

Bruns, W. (1974). The role of state and local consumer protection agencies in advertising regulation. In $\mathrm{F}$. Stuart (Ed.), Consumer protection from deceptive advertising (pp. 26-40). Hempstead, NY: Hofstra University Press.

Carpenter, D. (2010). Reputation and power: Organizational image and pharmaceutical regulation at the FDA. Princeton, NJ: Princeton University Press.

Carson, J. W. (2011). Self-regulation in securities markets (Working Paper no. 5542). Washington, DC: World Bank.

Cerra, F. (1978, January 8). New Better Business Bureau chief is consumer oriented. New York Times.

Changing Times. (1965, October). What is a Better Business Bureau anyhow? Changing Times, pp. 17-19.

Chicago Tribune. (1933, December 4). Better Business Bureau will act as NRA meditator. Chicago Tribune.

Congressional Record. (1971, December). Report on the Better Business Bureaus. Congressional Record, 111, 47781-47795.

Coombs, T., \& Holladay, S. (2011). Self-regulatory discourse: Corrective or quiescent? Management Communication Quarterly, 25, 494-510.

De Moor, T. (2008). The silent revolution: A new perspective on the emergence of commons, guilds, and other forms of corporate collective action in Western Europe. International Review of Social History, 53(16), 179-212.

Federal Trade Commission. (1958). Guide against deceptive pricing. Washington, DC: Federal Trade Commission.

Federal Trade Commission. (1959). Guide against bait advertising. Washington, DC: Federal Trade Commission.

Federal Trade Commission. (1966). Press release.

Fox, S. (1984). The mirror makers: A history of advertising and its creators. New York, NY: Morrow.

Grisinger, J. (2012). The unwieldy American state: Administrative politics since the new deal. New York, NY: Cambridge University Press.

Gunningham, N., \& Johnstone, R. (1999). Regulating 
workplace safety: Systems and sanctions. Oxford: Oxford University Press.

Gunningham, N., \& Rees, J. (1997). Industry selfregulation: An institutional perspective. Law \& Policy, 19(4), 363-414.

Havinga, T. (2006). Private regulation of food safety by supermarkets. Law \& Policy, 28(4), 515-533.

Hawley, E. (1981). Three facets of Hooverian associationalism: Lumber, aviation, and movies, 1921-1930. In T. McCraw (Ed.), Regulation in perspective: Historical essays (pp. 95-123). Cambridge, MA: Harvard University Press.

Justia. (2016). McCann v. New York Stock Exchange, 107 F.2d 908 (2d Cir. 1939). Justia. Retrieved from http://law.justia.com/cases/federal/appellate-courts/ F2/107/908/1495396

Kenner, H. J. (1936). The fight for truth in advertising. New York, NY: Round Table Press.

King, A., \& Lennox, M. (2000). Industry self-regulation without sanctions: The chemical industry's response to responsible care. Academy of Management Journal, 43(4), 701-704.

Lears, J. (1994). Fables of abundance: A cultural history of advertising in America. New York, NY: Basic Books.

Los Angeles Sentinel. (1979, October 11). BBB arbitrates repair disputes. Los Angeles Sentinel.

Marchand, R. (1986). Advertising the American dream. Berkeley, CA: University of California Press.

McCraw, T. K. (1982). With consent of the governed: SEC's formative years. Journal of Policy Analysis and Management, 1(3), 346-370.

Murphy, C., \& Yates, J. (2009). The international organization for standardization (ISO): Global governance through voluntary consensus. New York, NY: Routledge.

National Better Business Bureau Bulletin. (1967, May). Public awareness of NBBB at high level. National Better Business Bureau Bulletin.

New York City Better Business Bureau. (1933). Helping business and the NRA. New York, NY: New York City Better Business Bureau.

New York Times. (1930, November 11). President defines sound advertising. New York Times.

O'Sullivan, D. (1933). Rackets: An expose of the methods and practices of the Better Business Bureaus. Chicago: O'Sullivan Publishing House.

Oldenburg, D. (1997, June 7). BBB new online seal. Fort Lauderdale Sun Sentinel.

Porter, T., \& Ronit, K. (2006). Self-regulation as policy process: The multiple and criss-crossing stages of private rule-making. Policy Science, 39(1), 59-61.
Riegel, E. (1931). The indictment of the Better Business Bureau conspiracy. New York.

Roos, D. (2008). Criticism of Better Business Bureaus. HowStuffWorks.com. Retrieved from http://money. howstuffworks.com/better-business-bureau5.htm

Sharma, L. L., Teret, S. P., \& Brownell, K. D. (2010). The food industry and self-regulation: Standards to promote success and to avoid public health failures. American Journal of Public Health, 100(2), 240-246.

Stole, I. (2006). Advertising on trial: Consumer activism and corporate public relations in the 1930s. Urbana, IL: University of Illinois Press.

The Boston Better Business Commission. (1922). Annual report. Boston: The Boston Better Business Commission.

The Boston Better Business Bureau Bulletin. (1929, November 7). No libel action lost. The Boston Better Business Bureau.

The Lance. (1933, June). Shoppers as snoopers. The Lance, pp. 1, 8.

The New York Better Business Bureau. (1926). The Record recounting the advertising price claims of $R$. H. Macy \& Company, Inc., and the position of the Better Business Bureau of the New York City, in respect thereto. New York, NY: The New York Better Business Bureau.

The Yale Law Journal. (1953). Trade rules and trade conferences: The FTC and business attack deceptive practices, unfair competition, and antitrust violations. Yale Law Journal, 62(21), 912-953.

Tuttle, B. (2013). Why the Better Business Bureau should give itself a bad grade. Time. Retrieved from http:// business.time.com/2013/03/19/why-the-better-busi ness-bureau-should-give-itself-a-bad-grade

Uekoetter, F. (1999). Divergent responses to identical problems: Businessmen and the smoke nuisance in Germany and the United States, 1880-1917. The Business History Review, 73(4), 641-676.

Van Cise, J. (1966). Regulation-By business or government. Harvard Business Review, 44(2), 53-63.

Vogel, D. (2010). The private regulation of global corporate conduct: Achievements and limitations. Business \& Society, 49(1), 68-87.

Wall Street Journal. (1976, October). Sears Roebuck consents to order by FTC barring "bait-and-switch" sales tactics. Wall Street Journal.

Young, J. H. (1961). The toadstool millionaires: A social history of patent medicines before federal regulation. Princeton, NJ: Princeton University Press.

Zanot, E. (1979). The National Advertising Review Board. Lexington, KY: Association for Education in Journalism. 


\section{About the Author}

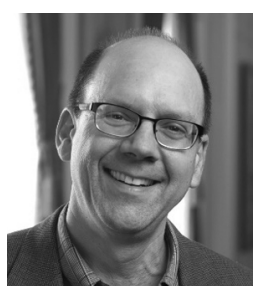

Edward J. Balleisen is Vice Provost for Interdisciplinary Studies (VPIS) at Duke, as well as Associate Professor of History and Public Policy. Balleisen has written widely on the historical intersections among law, business, and policy in the United States, as well as the evolution of American regulatory institutions and contemporary debates on regulatory governance. His next book, Fraud: An American History from Barnum to Madoff, will be published by Princeton University Press early in 2017. 